\section{Discussion}

Our results confirm other reports of the clinical effectiveness of this therapy (Anderson and Arner, 1972; Edwards et al., 1973) and so justify the plan to synthesize this analogue of vasopressin (Zoral and Storm, 1966). Twice-daily intranasal DDAVP completely controlled the diabetes insipidus in all our patients. Included were patients whose severe diabetes insipidus could not be controlled by chlorpropamide even when supplemented with LVP nasal spray and so had been managed with intramuscular vasopressin tannate in oil. The intranasal DDAVP method of treatment was preferred by all the patients and also achieved better control of their diabetes insipidus without any side effects.

There is no doubt that there was a need for this improvement in the replacement therapy of vasopressinsensitive diabetes insipidus. Unfortunately nephrogenic diabetes insipidus can still only be poorly controlled by the use of thiazides and restricting salt intake (Schotland et al., 1963). For mild cases of vasopressin-sensitive diabetes insipidus oral chlorpropamide (Wales and Fraser, 1971), clofibrate (De Gares et al., 1970), or carbamezipine (Braunhofer and Zicha, 1966) has been proved fully adequate. Slightly more severe cases may be fully controlled if one of these drugs is supplemented by intranasal LVP (Wales and Fraser, 1971). But hitherto for severe vasopressin-sensitive diabetes insipidus adequate control has been possible only with intramuscular vasopressin tannate in oil, whose duration of action of ten varies from inadequate shaking and warming of the phial before injection.

DDAVP is an improvement in several ways. The pure synthetic compound can be given intranasally without causing rhinitis or even the severe pulmonary reactions produced at times by vasopressin snuff (Pepys et al., 1965; Mahon et al., 1967) and years of rhinitis from this snuff may sub- side when the patient changes from the snuff to intranasal DDAVP, as our case 2 showed. Administration of accurately measured dosage can be achieved with the nasal catheter method of administration (Rhinyl, Ferring A.B.). As hoped by the synthesists (Zoral and Storm, 1966) the amino-acid substitutions involved have eliminated the pressor effects from the doses needed for replacement therapy and produced resistance to degradation so that it persists longer at the site of action (Vara et al., 1968; Edwards et al., 1973). For the occasional patients for whom intranasal administration may not be possible-for example, those with rhinorrhoea or nasal infections-DDAVP can offer the alternative control by single daily intramuscular injections.

We are grateful to Dr. Elizabeth Hughes and staff of the child health laboratory for the osmolality measurements, to Sister Kathleen Boon and staff of the metabolic unit, and to Dr. J. Mulder, research director (Ferring Pharmaceuticals), for the supply of DDAVP.

\section{References}

Anderson, K. E., and Arner, B. (1972). Acta Medica Scandinavica, 192, 21. Arduino, F., Ferroz, F. P. J., and Rodrigues, J. (1966). Fournal of Clinical Endocrinology, 26, 1325 .

Braunhofer, J., and Zicha, L. (1966). Medizinische Welt, 2, 1875.

Dashe, A. M., et al. (1964). Fournal of the American Medical Association, 190, 1069.

De Gares, J. L., et al. (1970). Annales d'Endocrinologie, 31, 300.

Edwards, C. R. W., et al. (1973). British Medical fournal, 3, 375.

Fraser, T. R., Joplin, G. F., and Steiner, R.

Mahon, W. E et al (1967). Thorax, 22, 13.

Pepys, W. E., et al. (1967). Thorax, 22, 13.

Schotland, M. G., Grunbach, M. M., and Strauss, J. (1963). Pediatrics, 31, 741 .

Vara, J., et al. (1968). Lancet, 1, 948.

Wales, J. K., and Fraser, T. R. (1971). Acta Endocrinologica, 68, 725.

Zoral, M., and Stcrm, F. (1966). Collections of Czechoslovak Chemical Communications, 31, 310 .

\title{
Thyroid Function in Patients Treated with Radioactive Iodine for Thyrotoxicosis
}

\author{
W. M. G. TUNBRIDGE， P. HARSOULIS， A. W. G. GOOLDEN
}

British Medical fournal, 1974, 3, 89-92

\section{Summary}

A series of 105 patients treated at least two years earlier with radioactive iodine for thyrotoxicosis have been surveyed. Eighty-five patients $(81 \%$ ) were euthyroid clinically and on the basis of routine thyroid function tests. Of the euthyroid patients $46(54 \%)$ had normal thyroid-stimulating hormone (TSH) levels and $39(46 \%)$ had raised TSH levels. There was no difference in serum triiodothyronine levels between these two groups but the serum protein bound iodine and serum thyroxine, though still well within the normal range, were significantly lower in the group with raised

\footnotetext{
Departments of Medicine and Radiotherapy, Hammersmith Hospital, London W12 0HS

W. M. G. TUNBRIDGE, M.B., M.R.C.P., Registrar (Presen appointment: Senior Research Assistant, Royal Victoria Infirmary, Ivewcastle upon Tyne)

TSH levels. The serum cholesterol was also significantly higher in this latter group.

Most of the euthyroid patients were seen again a year later. None had become hypothyroid and neither those with normal nor those with raised TSH levels showed any evidence of a decline in the level of serum thyroxine.

It is concluded that raised serum TSH levels in patients treated with iodine-131 are not necessarily indicative of hypothyroidism. There is no indication that patients who have this abnormality become overtly hypothyroid over a 12-month follow up.

\section{Introduction}

It is now well known that many patients treated with radioactive iodine for thyrotoxicosis eventually become hypo- 8 thyroid. This complication may occur in a relatively acute form within a few months of treatment, at which time it is not difficult to diagnose, or it may develop insidiously many $\stackrel{F}{\rightleftharpoons}$ years later, in which case it may be more difficult to recognize. ${ }^{131}$ I-treated patients evidently need prolonged and careful supervision. The recognition of hypothyroidism in such a population might seem to present no problem, but in 
practice it is often difficult to decide whether a patient is suffering from thyroid deficiency, and thyroid function tests are less helpful in these circumstances than they are in patients who have not had any previous treatment.

Though primary thyroid failure is invariably accompanied by an increase in the level of serum TSH (Odell et al., 1967; Hall, 1972) raised TSH levels have been found in conditions where there is no clinical evidence of hypothyroidism. An investigation of patients treated by subtotal thyroidectomy for thyrotoxicosis showed raised TSH levels in many who were clinically euthyroid and in whom the results of conventional thyroid function tests were normal (Hedley et al., 1971). Similar observations have been made in patients treated with radioactive iodine (Slingerland et al., 1972; Toft et al., 1973). The term subclinical hypothyroidism has been used to describe patients who fall into this category (Hall, 1972). Patients who have been treated with ${ }^{131} \mathrm{I}$ can be expected to show varying degrees of thyroid failure. We have examined a group of ${ }^{131}$ I-treated patients in an attempt to define more precisely the significance of raised serum TSH levels and in particular to determine whether this abnormality is an indication of existing or impending thyroid failure.

\section{Patients and Methods}

The patients investigated had been treated with ${ }^{131} I$ for thyrotoxicosis between 1954 and 1970. They were attending a long-term thyroid follow-up clinic to which they had been transferred only if they were considered to be euthyroid one year after receiving treatment with ${ }^{131}$ I. Since 1965 patients who did not become euthyroid after a single treatment with ${ }^{131}$ I were subsequently treated with carbimazole until they were considered to be in remission. These patients who needed additional treatment with an antithyroid drug were not transferred to the long-term follow-up clinic till they had remained euthyroid for at least six months after stopping the drug. No patient already taking thyroxine was included in the study.

Thyroid status was assessed clinically and on the basis of routine thyroid function tests excluding serum TSH and serum triiodothyronine (T-3). The routine tests included measurement of serum protein bound iodine (P.B.I.), serum thyroxine (T-4), serum cholesterol, and free thyroxinebinding globulin (T.B.G.) capacity. An electrocardiogram was recorded in certain patients who underwent a therapeutic trial of thyroxine.

Serum P.B.I. was measured by autoanalyser (normal range 4.0-8.0 $\mu \mathrm{g} / 100 \mathrm{ml}$ ). Serum T-4 was measured by a competitive protein binding assay using a modification of the method of Murphy (1965; normal range 5.4-11.8 $\mu \mathrm{g} / 100 \mathrm{ml}$ ). Within assay variation was $3.8 \%$ and between assay variation was $7 \cdot 6 \%$, Serum T-3 was measured by radioimmunoassay of unextracted serum in about half of the patients (Eastman et al., 1973; normal range $800-1,600 \mathrm{pg} / \mathrm{ml}$ ). Serum TSH was measured in all patients by radioimmunoassay according to the method of Hall et al. (1971) with slight modifications using Medical Research Council 63/14 standard HTSH. The normal range of serum TSH was $<1.0-4.5 \mu \mathrm{U} / \mathrm{ml}$; within assay variation was $2.5 \%$ and between assay variation was $15 \%$.

Thyrotrophin-releasing hormone (TRH) tests were carried out as described by Tunbridge et al. (1973). Serum cholesterol was determined using Technicon method N24a (normal range $140-260 \mathrm{mg} / 100 \mathrm{ml}$ ). Free T.B.G. capacity was measured using a Sephadex column (Gimlette, 1967).

\section{FOLLOW UP}

The survey started in February 1972. Most of the euthyroid patients (76 out of 85) were seen again after an interval of one year. Thyroid status was assessed clinically and thyroid func- tion tests, including measurement of serum $\mathrm{T}-4$ and serum $\mathrm{TSH}$, were repeated.

\section{Results}

The patients were classified into five different groups on the basis of the clinical assessment and the results of routine thyroid function tests. The euthyroid group was further subdivided according to whether serum TSH was normal or raised (table I). Serum T-3 levels were not taken into consideration in this classification. The results are expressed as means \pm S.E. of mean.

TABLE I-Classification of 105 Patients Treated with ${ }^{131} I$ according to Clinical Findings and Results of Thyroid Function Tests

$\left.\begin{array}{c|l|c}\hline \text { Group } & \multicolumn{1}{|c}{\text { Thyroid Status }} & \text { No. (\%) of Patients } \\ \hline 1 & \text { Thyrotoxic (All criteria) } & 2 \\ 2 & \text { Thyrotoxic (Tests only) } & 5 \\ 3 & \text { Euthyroid (All criteria) } & 46 \\ 4 & \text { Euthyroid (All criteria except TSH level) } & 39 \\ 5 & \text { Hypothyroid* (Tests only) } & 4 \\ 6 & \text { Hypothyroid (All criteria) } & 9\end{array}\right\}(12)$

*Two patients had normal serum T-3 levels.

Group 1.-Two patients were clinically thyrotoxic and the results of their thyroid function tests were in accordance with the clinical findings.

Group 2.-Five patients were clinically euthyroid but the results of thyroid function tests were indicative of hyperthyroidism. All the patients had P.B.I. and serum T-4 values above the upper limit of the normal range. In the four patients who were tested serum TSH did not rise in response to TRH, the response being similar to that seen in hyperthyroid patients (Ormston et al., 1971). Three patients were treated with carbimazole $30 \mathrm{mg}$ daily for a month. Though this resulted in a fall in the P.B.I. to within the normal range none of the patients felt any better and in none could we detect any clinical change.

Group 3.-Forty six patients, $44 \%$ of the total number surveyed, were euthyroid by all criteria and by definition had normal TSH levels. The results of the tests are shown in table II.

TABLE II-Results of Thyroid Function Tests in Patients from Groups 3 and 4 Values are expressed as Means \pm S.E. of Mean. Numbers of Patients are given in Parentheses.

\begin{tabular}{|c|c|c|c|c|c|}
\hline & $\begin{array}{l}\text { P.B.I. } \\
(\mu \mathrm{g} / 100 \mathrm{ml})\end{array}$ & $\begin{array}{c}\mathrm{T}-4 \\
(\mu \mathrm{g} / 100 \mathrm{ml})\end{array}$ & $\begin{array}{c}\mathrm{T}-3 \\
(\mathrm{pg} / \mathrm{ml})\end{array}$ & $\begin{array}{c}\text { Free T.B.G. } \\
\text { Capacity }\end{array}$ & $\begin{array}{l}\text { Cholesterol } \\
(\mathrm{mg} / 100 \mathrm{ml})\end{array}$ \\
\hline $\begin{array}{l}\text { Normal range } \\
\text { Group } 3 \text { (46) } \\
\text { Group } 4 \text { (39) }\end{array}$ & $\begin{array}{c}4-8 \\
6 \cdot 7 \pm 0 \cdot 15 \\
\left(\frac{ \pm 3)}{(43)}\right. \\
5 \cdot 5 \pm \cdot 17 \\
(38)\end{array}$ & 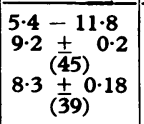 & $\begin{array}{c}800-1600 \\
1105 \pm 66 \\
(23) \\
1170 \pm \\
(24)\end{array}$ & 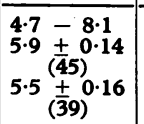 & $\begin{array}{l}140-260 \\
243 \pm 7 \\
(31) \\
279 \pm 7.5 \\
(36)\end{array}$ \\
\hline $\mathbf{P}$ & $<\cdot 001$ & $<.01$ & N.S. & N.S. & $<\cdot 001$ \\
\hline
\end{tabular}

Group 4.-Thinty-nine patients, $37 \%$ of the total number surveyed, were euthyroid by clinical criteria and on the basis of conventional thyroid function tests, but they had significantly raised TSH levels. (See fig.) The results of the other tests are shown in table II). Of the 39 patients in this group 13 were further investigated by testing their response to TRH and by treating them with thyroxine $0.1 \mathrm{mg}$ daily for a month, after which the dose was increased to $0.2 \mathrm{mg}$ daily for a further month. TSH levels were measured before treatment, after one month on $0.1 \mathrm{mg}$ of thyroxine, and after one month on $0.2 \mathrm{mg}$ of thyroxine. The serum cholesterol was measured and an electrocardiogram recorded at the same time intervals. The 
exaggerated response to TRH was similar to that seen in patients with primary hypothyroidism in all except one patient, who had a marginally raised basal TSH but a normal increment. Thyroxine produced no subjective or objective changes in any of the patients. TSH levels fell after taking $0 \cdot 1$ $\mathrm{mg}$ of thyroxine, and normal levels were found in all the patients after they had taken $0.2 \mathrm{mg}$ of thyroxine for a month. There was no change in the serum cholesterol after the 0.1mg dose. Several patients had abnormal electrocardiograms before treatment, but the abnormalities, with two exceptions, were not those commonly seen in hypothyroidism. One patient had a sinus tachycardia and another had a sinus bradycardia with low-voltage $T$ waves, but neither in these patients nor in any of the others was there any change after taking thyroxine.

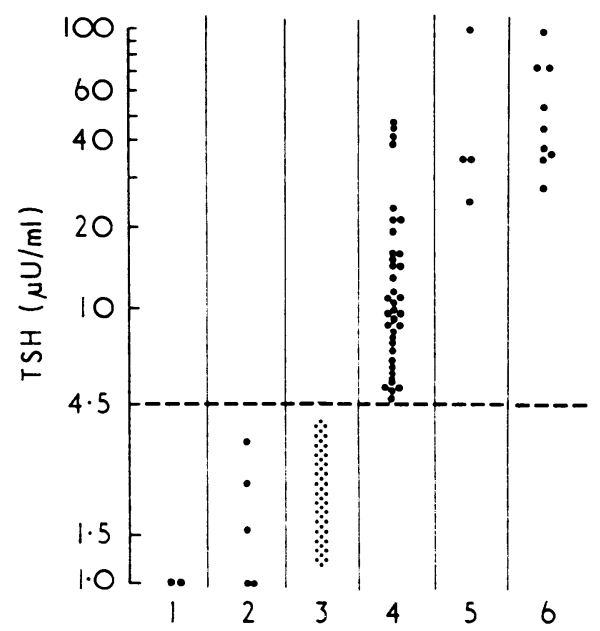

Serum TSH values in all groups of patients: broken line represents upper limit of normal.

Group 5.-Four patients were asymptomatic and clinically euthyroid, but the results of the tests were on balance indicative of hypothyroidism. Serum cholesterol was raised in all four patients (range $330-370 \mathrm{mg} / 100 \mathrm{ml}$ ). Values for at least two of the other three routine thyroid function tests (PBI, serum T-4, free T.B.G. capacity) were below the lower limit of the normal range. TSH levels were raised (see fig.), but in two of the three patients for whom results were available serum T-3 values were normal $(850$ and $920 \mathrm{pg} / \mathrm{ml})$. A third patient had a serum T-3 of $600 \mathrm{pg} / \mathrm{ml}$. All four patients were given a therapeutic trial of thyroxine. Two felt no better and showed no changes clinically, but their serum cholesterol fell significantly after a month on $0.1 \mathrm{mg}$ of thyroxine and became normal after the dose was increased to $0.2 \mathrm{mg}$. For this reason treatment was continued. The third patient did not feel well on thyroxine and there was no significant fall in serum cholesterol. Treatment was therefore discontinued. The remaining patient, a woman aged 77 , had both low serum $\mathrm{T}-4$ and low serum $T-3$ levels. She tolerated treatment with thyroxine, which was gradually increased to $0.15 \mathrm{mg}$ daily and her serum cholesterol fell significantly. Two weeks after she had been discharged from hospital she had a myocardial infarct, and treatment with thyroxine was accordingly discontinued. She subsequently developed overt symptoms and signs of hypothyroidism.

Group 6.-Nine patients were hypothyroid by all criteria including raised TSH levels. (See fig.) They all responded to treatment with thyroxine.

\section{COMPARISON OF GROUPS 3 AND 4}

Mean values of P.B.I. serum T-4, serum T-3, free T.B.G. capacity, and serum cholesterol for the patients in groups 3 and 4 are compared in table II. The patients in group 3 had a significantly higher P.B.I. $(P<.001)$ and serum T4 (P $<0 \cdot 1)$ than those in group 4 though for both groups all values were within the normal range. Serum cholesterol, on 0 the other hand, was significantly higher for the patients in group 4 than for those in group $3(\mathrm{P}<\cdot 001)$. Values for serum $\Phi$ T-3 and for free T.B.G. capacity did not differ significantly between the two groups nor was there any difference in $\Rightarrow$ respect to age.

\section{FOLLOW-UP}

Most patients (89\%) in groups 3 and 4 were seen again one year later. No patient in either group showed any clinical $\vec{\circ}$ evidence of hypothyroidism. Mean values for serum TSH and. serum T-4 for 1972 and 1973 are compared in table III. For $\vec{\omega}$ both groups the mean values for serum TSH were higher in 0 1973 than in 1972. For both groups values for serum T-4 $\frac{5}{3}$ showed no significant difference between 1972 and 1973, but in 1973 the mean value for the patients in group 3 was again in higher than that of the patients in group 4.

TABLE III-Mean Values ( \pm S.E. of Mean) for Serum TSH and T-4 for $\stackrel{ }{2}$ Patients from Groups 3 and 4 in 1972 and 1973. Numbers of Patients are given $\vec{\omega}$ in Parentheses.

\begin{tabular}{|c|c|c|c|c|c|c|}
\hline & \multicolumn{2}{|c|}{$\mathrm{TSH}(\mu \mathrm{U} / \mathrm{ml})$} & \multirow[b]{2}{*}{$\mathbf{P}$} & \multicolumn{2}{|c|}{$\mathrm{T}-4(\mu \mathrm{g} / 100 \mathrm{ml})$} & \multirow[b]{2}{*}{$\mathbf{P}$} \\
\hline & 1972 & 1973 & & 1972 & 1973 & \\
\hline $\begin{array}{l}\text { Group } 3 \\
\text { (41) } \\
\text { Group } 4 \\
(35)\end{array}$ & $\begin{array}{c}2 \cdot 1 \pm 0 \cdot 24 \\
(37) \\
14 \cdot 0+2 \cdot 0 \\
(00)\end{array}$ & $\begin{array}{c}3 \cdot 7+0 \cdot 39 \\
(37) \\
20 \cdot 4 \pm 2 \cdot 21 \\
(00)\end{array}$ & $\begin{array}{l}<.001 \\
<.001\end{array}$ & $\begin{array}{c}9.4 \pm 0.22 \\
8.3 \pm 0.23 \\
\left(\frac{13}{3} 3\right)\end{array}$ & $\begin{array}{l}9.5 \pm 0.22 \\
8.1 \pm 0.23 \\
\left(\frac{3}{33}\right)\end{array}$ & $\begin{array}{l}\text { N.S. } \\
\text { N.S. }\end{array}$ \\
\hline $\mathbf{P}$ & $<\cdot 001$ & $<\cdot 001$ & & $<\cdot 01$ & $<\cdot 01$ & \\
\hline
\end{tabular}

\section{Discussion}

This study of ${ }^{131}$ I-treated patients showed most $(81 \%)$ to be euthyroid both clinically and on the basis of routine thyroid function tests. The group as a whole, however, showed a wide range of thyroid malfunction with hyperthyroidism at one end of the scale and hypothyroidism at the other. In 3 some of the patients it was not difficult to recognize these abnormalities clinically, and the results of thyroid function $\frac{\rho}{3}$ tests were in accordance with the clinical findings, but in 0 other patients there seemed to be no correlation between the clinical state and the results of the tests. Our observations $N$ illustrate some of the difficulties of assessing thyroid status $D$ correctly in patients who have been treated with ${ }^{131} \mathrm{I}$.

Recurrent hyperthyroidism is rarely seen after ${ }^{131}$ I therapy. $N$ In this series there were two patients who were unquestionably hyperthyroid and five others (group 2) who though 0 clinically euthyroid must be considered hyperthyroid on the basis of their tests. The two patients who were recognized as being thyrotoxic had both been treated with an antithyroid $\stackrel{\infty}{\rightarrow}$ drug after their treatment with ${ }^{131} I$ and it is likely that they $T$ relapsed after having had temporary drug-induced remissions. The patients in group 2 presented considerable problems from $\stackrel{\mathbb{D}}{\stackrel{D}{\circ}}$ both the diagnostic and therapeutic viewpoint. Most of them $\stackrel{\mathbb{Q}}{\Omega}$ had been attending the clinic for several years. There was $\bar{\sigma}$ nothing in their records to suggest that they might have residual hyperthyroidism. They were asymptomatic and on $\frac{0}{0}$ clinical examination euthyroid. Routine thyroid function tests showed raised levels of circulating thyroxine which could not $\frac{0}{\partial}$ be attributed to any abnormality in the thyroid hormone binding proteins, and the TRH test result was consistent with hyperthyroidism. Though treatment with carbimazole for a month induced a significant fall in the P.B.I. none of the patients seemed to derive any clinical benefit from this pro- 
cedure. It is difficult to offer any explanation for the lack of correlation between clinical state and test results in these patients who could be regarded as having subclinical hyperthyroidism (Hall et al., 1973).

The four patients in group 5 presented a similar sort of problem to those in group 2 though in this case the question was whether or not they were hypothyroid. Clinically they seemed to be euthyroid but they had low serum T-4 levels. Serum T-3 levels in two of these patients on the other hand were within the normal range. Some patients who have been treated with ${ }^{131} \mathrm{I}$ have been found to have low serum T-4 levels in association with raised or normal serum T-3 levels (Sterling et al., 1969, Bellabarba et al., 1972), and it has been suggested that normal thyroid status is achieved in this situation by an alteration in the serum $\mathrm{T} 3: \mathrm{T} 4$ ratio. It was to be expected that among the patients we surveyed there would be some who showed this phenomenon. It seems that at least two of the patients in this group were euthyroid, perhaps because they were preferentially producing $\mathrm{T}-3$. We conclude that the 77-year-old woman who did have a low serum $\mathrm{T}-3$ level and the highest TSH value recorded in the series (see fig.) was in fact hypothyroid despite the absence of a therapeutic response to thyroxine.

It is generally agreed that the secretion of thyroid hormone is regulated by means of a feedback mechanism. According to this concept TSH levels can be expected to increase when blood concentrations of T-3 or T-4 or both are suboptimal. It would seem that the feedback mechanism is essentially normal in patients with thyrotoxicosis whether the condition is active or in remission after treatment. (Adams and Kennedy, 1965; Pinchera et al., 1965). Eighty five (81\%) of the patients we investigated were assessed as being euthyroid on the basis of clinical examination and thyroid function tests, but $39(46 \%)$ of these patients had raised TSH levels. The implication is that nearly half the patients who seemed to be euthyroid were suffering from thyroid hormone insufficiency.

It could be argued that the T-4 levels in the euthyroid patients with raised serum TSH levels though falling within our observed normal range were nevertheless below the optimum levels for this particular group of individuals. In support of this argument is the fact that these patients had lower levels of $\mathrm{T}-4$ than the group 3 patients. If group 3 were indeed euthyroid then the raised serum TSH levels in the group 4 patients could be attributed to suboptimal levels of T-4, an explanation which is consistent with conventional views about the feedback mechanism. The mean serum cholesterol level was higher in group 4 patients than in group 3 patients and this might also be interpreted as evidence of thyroid hormone insufficiency. There was, however, no decrease in the serum cholesterol levels when the patients were given thyroxine though serum TSH levels did fall to within the specified normal range.

The mean value for serum T-4 in the group 4 patients was $8.3 \mu \mathrm{g} / 100 \mathrm{ml}$, which is very close to our mean value for normal subjects $(8.6 \mu \mathrm{g} / 100 \mathrm{ml})$. It seems unlikely therefore that they had inadequate levels of T-4 unless before the onset of thyrotoxicosis they constituted a group having a mean T-4 level higher than that of normal people. There was no difference in serum T-3 levels between groups 3 and 4, and furthermore, all serum $T-3$ values for both groups fell within the normal range. It was impossible to measure serum $\mathrm{T}-3$ in all the euthyroid patients, but there are probably enough values to be representative of each group as a whole. Since both serum T-4 and serum T-3 levels were within normal limits it is difficult to concede that the patients in group 4 were suffer- ing from thyroid hormone insufficiency. In reaching this conclusion we have had to disregard the raised serum TSH levels whose significance we are trying to evaluate.

The follow-up data suggest that thyroid status and thyroid function changed very little during the course of a year in patients in groups 3 and 4 . None of the patients with raised TSH levels in 1972 showed any evidence of hypothyroidism a year later, and there was little if any evidence of a fall in serum T-4 levels. The serum TSH levels in both groups were higher in 1973 than 1972, but these differences were within the limits for interassay variation. Comparison of the 1972 and 1973 serum TSH levels is open to criticism because the original samples were not reassayed with the follow-up samples a year later. This was impossible due to technical difficulties with our serum T-3 assay, which was eventually done elsewhere and for which all the remaining serum was required. Our data about raised serum TSH levels in ${ }^{131} I-$ treated patients who by other criteria are euthyroid are in agreement with the observations of Toft et al. (1973), and we conclude, as they do, that raised serum TSH levels in such patients are not necessarily indicative of impending clinical hypothyroidism. Some of the patients who are euthyroid at present, however, can be expected to become hypothyroid eventually. It may well be that the patients with raised serum TSH levels are at greater risk in this respect.

If the patients in group 4 were not hypothyroid, we may question both the significance and mechanism of raised serum TSH levels in these circumstances. It is difficult to provide an explanation which is consistent with conventional views about the feedback mechanism. Possibly some factor other than the level of circulating thyroid hormones may be capable of provoking an increase in TSH secretion. Such a factor might be related to a reduction in the mass of functioning thyroid tissue. It has been known for some time that the rate of turnover of iodine in the thyroid is increased in many patients treated with ${ }^{131} \mathrm{I}$. This acceleration in the intrathyroidal turnover of iodine could well be sustained by $\mathrm{TSH}$, which might have to be secreted in excess of normal amounts to maintain normal thyroid status.

We thank Professor Roger Ekins for carrying out the serum T-3 measurements and the department of clinical pathology for the serum P.B.I. determinations.

Requests for reprints should be sent to Dr. A. W. G. Goolden.

\section{References}

Adams, D. D., and Kennedy, T. H. (1965). Fournal of Clinical Endocrinology and Metabolism, 25, 571 .

Bellabarba, D., Benard, B., and Langlois, M. (1972). Clinical Endocrinology, 1,345 .

Eastman, C. J., et al. (1973). Fournal of Endocrinology, 58, xxii.

Gimlette, T. M. D. (1967). Fournal of Clinical Pathology, 20, 170.

Hall, R. (1972). Clinical Endocrinology, 1, 115

Hall, R., Amos, J., and Ormston, B. J. (1971). British Medical fournal, 1, 582.

Hall, R., Evered, D., and Tunbridge, W. M. G. (1973). In Ninth Symposium on Advanced Medicine, ed. G. Walker. London, Pitman Medical.

on Advanced Medicine, ed. G. Walker.
Hedley, A. J., et al. (1971). Lancet, $1,455$.

Murphy, B. P. (1965). Fournal of Laboratory and Clinical Medicine, 66, 161. Murphy, B. P. (1965). Fournal of Laboratory and Clinical Medicine, 66, 161.
Odell, W. D., Wilber, J. F., and Utiger, R. D. (1967). Recent Progress in
Hormone Research, 23, 47.

Hormone Research, 23,
Ormston, B. J., et al. (1971). Lancet, 2, 10.

Ormston, B. J., et al. (1971). Lancet, 2, 10. Endocrinology and Metabolism, 25, 189.

Slingerland, D. W., et al. (1972). Fournal of Clinical Endocrinology and Metabolism, 35,'912.

Sterling, K., et al. (1969). Fournal of Clinical Investigation, 48, 1150. Sterling, K., et al. (1971). Fournal of Clinical Endocrinology and Metabolism,

Toft, A. D., et al. (1973). Lancet, 2, 644. Tunbridge, W. M. G., et al. (1973). Proceedings of the Royal Society of
Medicine, 66, 187. 